\title{
discussion
}

\section{Inconsistency: A Fallacy?}

JULIAN WOLFE

One of the informal fallacies discussed by Blair and Johnson in their text Logical Self-Defense is that of inconsistency.[1] No doubt there are some forms of inconsistency which are clearly correct to describe as fallacious. For example, if either the premises of an argument contradict one another, explicitly or implicitly, or a premise or what it entails or presupposes and the conclusion do so, then the argument is undermined in that not all the statements contained in it can be true.

However, the authors claim that a fallacy of inconsistency may occur when there is an inconsistency between what a person preaches and what that person practices. Since by "fallacy" they mean "a violation of one of the criteria which govern good arguments," [2] one presumes that it is in the context of argument that the fallacy of inconsistency might arise. Indeed, the authors say as much:

It is not a fallacy to assert inconsistent statement or to behave inconsistently with one's pronoucements. The fallacy occurs only when inconsistency of one sort or another undermines an argument.[3]

So if a mother tells her teenage son that he should not smoke, and does so herself, there is an inconsistency, but no fallacy unless she gives the teenager reasons why he should not smoke, i.e., argues for her viewpoint.

The question I pose is how inconsis-
Carleton University

tency between assertion and action can undermine an argument and thus constitute a fallacy. If the mother tells her son that he should not smoke because it is harmful to his health as well as that of other children in the family who are forced to inhale the fumes second hand, how are these reasons shown not to be good reasons if the mother herself smokes?

Inconsistency between preaching and practice can be evidence of addiction ("I know I shouldn't smoke but I just can't quit"), selfishness (" I keep telling myself to give more to charity but I really like new clothes and travel"), or weakness ("I feel guilty about my infidelities, but I'm not strong enough to always resist temptation $\left.^{\prime \prime}\right)$. The reasons one offers in opposition to smoking and adultery, or in favour of charity, may be good ones even if one doesn't always practice what one preaches. People don't always live up to their convictions, but their convictions may be defensible and defended with good reasons.

Blair and Johnson give the example of Canadian officials who exhort Canadians to winter vacation at home, while vacationing themselves during the winter in Florida and the Caribbean. We are asked to imagine the following argument made by the officials to persuade Canadians to take winter holidays in Canada.[4] 
(a) To help Canada's balance-ofpayments position, as many Canadian dollars should be kept in the country as possible,

(b) The Canadian economy would benefit from increased spending in our winter tourism and entertainment industries,

(c) So Canadians should spend their winter holiday money at home in Canada.

Given the inconsistency between the preaching and practice of these officials, shall we conclude that the above argument commits a fallacy of inconsistency? How does their behaviour undermine the argument? Does it show that (a) and (b) are not good reasons for (c) or don't adequately support it? Surely not. Blair and Johnson go on to say:

Yet many of these same officials who vacationed in Florida and the Caribbean must have been operating on some such principle as the following:

PR: It is not imperative that Canadians spend their winter holiday money at home in Canada[5].

Their point is that the behaviour of these officials indicates they accept a principle that contradicts the conclusion (c).

However, in the first place, PR is neither entailed nor presupposed by either (a) or (b), and hence there is no inconsistency, within the argument itself. The argument is not undermined. Second, the officials needn't be assumed to be operating on PR. They may be simply be failing to live up to their own convictions. After all, warm weather is very attractive to Canadians during our cold winters, and too tempting for some to resist. Charged with inconsistency, our officials may just admit to acting wrongly.

I suggest that to charge inconsistency as a fallacy in such cases is itself to commit a fallacy, a type of ad hominem. Its form form is:

He doesn't practice what he preaches So, he can't adequately defend what he preaches

or

What he preaches is mistaken.

\section{Notes}

[1] R.H. Johnson and J.A. Blair, Logical Self-Defense (McGrawHill Ryerson, 1983, 2nd edition, pp. 59-63.

[2] Ibid, p. 33

[3] Ibid., P. 60.

[4] Ibid., p. 61.

[5] Ibid., p. 61.

Professor Julian Wolfe, Department of Philosophy, Carleton University, Ottawa, Ontario K1S 5B6 